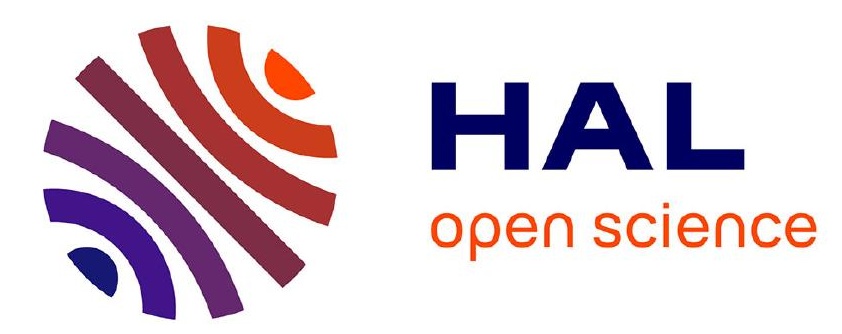

\title{
Fossil record of the Icacinaceae and its paleogeographic implications
}

Cédric del Rio, Dario de Franceschi

\section{To cite this version:}

Cédric del Rio, Dario de Franceschi. Fossil record of the Icacinaceae and its paleogeographic implications. Review of Palaeobotany and Palynology, 2020, 273, pp.104135. 10.1016/j.revpalbo.2019.104135 . mnhn-02559005

\section{HAL Id: mnhn-02559005}

\section{https://hal-mnhn.archives-ouvertes.fr/mnhn-02559005}

Submitted on 21 Dec 2021

HAL is a multi-disciplinary open access archive for the deposit and dissemination of scientific research documents, whether they are published or not. The documents may come from teaching and research institutions in France or abroad, or from public or private research centers.
L'archive ouverte pluridisciplinaire HAL, est destinée au dépôt et à la diffusion de documents scientifiques de niveau recherche, publiés ou non, émanant des établissements d'enseignement et de recherche français ou étrangers, des laboratoires publics ou privés.

\section{다)(1) $(5$}

Distributed under a Creative Commons Attribution - NonCommerciall 4.0 International 
1 Fossil record of the Icacinaceae and its paleogeographic implications

2

3 Cédric Del Rio ${ }^{1,2,3^{*}}$, Dario De Franceschi ${ }^{1}$

4

$5 \quad{ }^{1}$ CR2P - Centre de Recherche en Paléontologie - Paris. MNHN - Sorbonne Université -

6 CNRS, CP38, 57 rue Cuvier, 75231 Paris Cedex 05, France

7

$8 \quad{ }^{2}$ ISYEB - Institut de Systématique, Évolution, Biodiversité, CNRS, MNHN, Sorbonne-

9 Université, EPHE, CP39, 57 rue Cuvier, 75231 Paris Cedex 05, France

10

$11{ }^{3}$ CAS, Key Laboratory of Tropical Forest Ecology, Chinese Academy of Sciences, Mengla,

12 Yunnan 666303, China

13

$14 *$ Corresponding author: cedric.del-rio@edu.mnhn.fr 


\section{Abstract}

In the past decades, the concept of Icacinaceae has been refined greatly, as morphological and molecular data have led to a narrower circumscription of a monophyletic Icacinaceae family with only 23 genera (vs 58 sensu Sleumer, 1942). This family possesses an extensive fossil record, important to the biogeographic history of the Northern Hemisphere, but the reported fossils need to be carefully evaluated in the current phylogenetic framework. We evaluated 183 fossil reports of Icacinaceae from the literature but considered only 92 as reliably belonging to this family. Most of the accepted records are from endocarp remains. With this sampling, we show an increase of the species richness during the Paleocene. A great increase of diversity in terms of genera, species, and morphological range is shown through the Paleocene-Eocene interval and during the Early Eocene (Ypresian). Exchanges occurred between North America and Europe near the PETM in both directions. During the middle and late Eocene, several of the modern genera appear first in the fossil record such as Natsiatum, Phytocrene, and Pyrenacantha. Decreased diversity of post-Eocene records might be explained by cooling during and subsequent to the Oligocene, which was less favourable to climbers. We observe the same pattern in other megathermal families showing the global dynamic of megathermal groups of the North Hemisphere forest (boreotropical sensu. Wolfe, 1975) during the Paleogene. 


\section{Introduction}

In the past decades, the concept of Icacinaceae has been revised considerably with the results of new molecular and morphological data that show that the former Icacinaceae family concept with about 400 species and 58 genera (from Sleumer, 1942) was polyphyletic (Kårehed, 2001). That phylogenetic study defined the Icacinaceae s.s. as belonging to the Garryales order and placed some genera in the Aquifoliales and Apiales orders. In particular, Kårehed described a new family, Stemonuraceae, and added some species to the

Cardiopteridaceae family. The resulting circumscription of Icacinaceae included only 36 genera divided in four informal groups: Icacina, Cassinopsis, Emmotum, and Apodytes. Later, another study showed that this new circumscription of Icacinaceae corresponds to a basal lamiid group (Lens et al., 2008). According to Lens et al. (2008), the Icacinaceae have simple perforation plates in vessels (except for Cassinopsis), which is not the case for other excluded former Icacinaceae. However, the Icacinaceae (sensu Lens et al., 2008) was still considered as a polyphyletic group (Byng et al., 2014). More recently, a new Icacinaceae s.s. family was delimited with only the Icacina group sensu Kårehed (2001) accepted, using a new molecular data set (Stull et al., 2015). Icacinaceae s.s. (sensu Stull et al. 2015) contains only 23 genera, with about 160 species, and is a basal lamiid group close to the Oncothecaceae family. Both families are in the newly defined Icacinales order. Those taxonomic assignments are accepted and used in the APG IV (APG, 2016). Thus, the Icacinaceae family s.l. belongs now to four indirectly related orders in Asterids group (Fig.1).

This family possesses an extensive fossil record that extends geographically and geologically. The record is mainly composed of endocarps (e.g., Reid and Chandler, 1933; Manchester, 1994; Collinson et al., 2012) but there are also reports of wood (e.g., Greguss, 1969), pollen (e.g., Kedves, 1970; Krutzsch \& Vanhoorne, 1977; Cavagnetto, 2000), a flower 
(Del Rio et al., 2017) and leaf remains (e.g., Wolfe, 1977; Tanai, 1990). However, most of the paleobotanical discoveries and descriptions on Icacinaceae family were made before the twenty first century. Therefore, assignments to Icacinaceae were done before the recent modifications of the phylogenetic framework and some characters used to define Icacinaceae can be in fact been simply apomorphic for Asterids (Fig. 1).

Some fossil species (e.g., Icacinoxylon alternipuncata, Icacinicarya papillaris, and Iodes germanica), were used to calibrate an angiosperm phylogeny (Magallón et al., 2015). In addition, the Icacinaceae fossil remains have been used as a paleoclimatic clue and contributed to the characterization of the Boreotropical forest definition, a vegetation type that was widespread across middle latitudes in Northern Hemisphere during the Eocene (Wolfe, 1975). The Icacinaceae fossils also played an important role in the understanding of the dispersion between Europe and North America during the early-middle Eocene (Manchester, 1994; Stull et al., 2011; Allen et al., 2015). Thus, it is crucial to evaluate the Icacinaceae fossil record within a phylogenetic framework. Two reviews of the fossil record including the asteridae were made (Martínez-Millán, 2010; Manchester, 2015), highlighting a Maastrichtian minimum age for the Icacinaceae family. However, neither of these reviews embraces all the Icacinaceae fossils described until now.

In this study, we reviewed previously published reports of fossils attributed to the Icacinaceae. Our main questions are: (1) what is the fossil diversity of Icacinaceae s.s. following the new circumscription of the family and (2) what is the paleogeography and biogeographic history of this family based on this new circumscription? 
We compiled all the occurrences of Icacinaceae in the literature to the extent of our knowledge (Table 1.). The fossil record depends on available outcrops, search efforts, and findings. Here we took into consideration a majority of species from North America and Europe. This distribution is probably due to a more thorough search effort in this area than others in palaeobotanical history (Morley \& Dick, 2003). Indeed, Icacinaceae fossils were recently found from Paleocene-Miocene range in South America (Stull et al., 2012). The palaeobotanical studies of South-America have been increased during the last ten years (Herrera et al., 2011, 2014; Jud et al., 2016; Pérez-Consuegra et al., 2017, 2018), and reveal a new diversity and new biogeographical hypotheses, including for Icacinaceae. We tabulated 183 fossil occurrences according to the age, locality, country and the concerned organs, among them 105 (81 species) were represented by fossil of endocarps divided in 12 fossil genera: Comicilabium, Croomiocarpum, Faboidea, Hosiea, Icacinicarya, Icacinicaryites, Iodicarpa, Palaeohosiea, Palaeophytocrene, Perforatocarpum, Sphaeriodes and Stizocarya and four modern genera: Iodes, Natsiatum, Phytocrene and Pyrenacantha. Only one flower has been described for this family, the extinct genus Icacinanthium. We also compiled 13 leaf occurrences (10 species), five of them being from two extinct genera: Goweria and Huziokaeae and four of them from two extant genera: Merrilliodendron and Phytocrene. The pollen record includes 26 occurrences (seven species) in two fossil genera, Compositoipollenites and Echiperiporites, and only an extant ones Iodes. Finally, we recorded 38 occurrences (14 species) of fossil wood records, with two fossil genera, Icacinoxylon and Apodytoxylon. The dominance in the fossil record of climbing genera, well represented close to rivers, could be a taphonomic bias (Burnham, 1989; Burnham et al., 1992). However, because the climbing genera are well distributed in the family, we consider our sample as representative of the entire family. 
We decided to accept or reject occurrences based on the initial description and the associated figures in the literature. We checked all occurrences in accordance with new taxonomic and phylogenetic data (Stull et al. 2015). The Icacinaceae s.l. now belongs to four order in Asterids (Fig. 1), and thus some Icacinaceae characters used as criteria of fossil recognition (e.g., wood anatomy, leaves characters) cannot be longer used. We resumed the genera taxonomic changes and the associated fossil record in the Appendix 1.

We propose a reconstruction of the paleogeography of the Icacinaceae s.s. (Fig. 2) using paleomap made by Boucot et al. (2013). In this reconstruction (Fig. 2), the rejected occurrences are excluded (considered as definitively not Icacinaceae or without certainty in brief and global idea of the link between past climate and Icacinaceae distribution (Boucot et al., 2013). This climatic ancestral reconstruction was based on the presence of lithological remains: Coal, Bauxite and Laterite indicate a warm and wet climate (assumed as tropical), the Coal and Tillites together indicate a cold and wet climate (cool temperate), the presence of Evaporite and Calcrete indicates a warm and dry climate (arid), The tillite associated with Dropstone and Glendonite indicate a dry and cool climate (cold) and the presence of Kaolinite, Crocodiles remains, palms and mangroves indicate a warm temperate climate. For more clarity, the position of the different rocks samples was removed and we only kept the climatic area reconstructions. The complete lithological data can be found in the following website: scotese.com/climate.htm. Despite more recent alternative data on reconstruction of biomes for parts of the world (e.g., South America, Jaramillo and Cardenas, 2013), we 


\subsection{Species and occurrences rejected or dubious}

The endocarp record is the most meaningful for the Icacinaceae family, and probably the most reliable. However, some occurrences need to be revisited. Comicilabium atkinsii was considered as belonging to Icacinaceae by its unilocular endocarp, the vascular bundle on only one side and the cellular structure of the endocarp wall

142 (Manchester, 1994). The endocarp apical structure is a bulge with a lip. The size of the endocarp and the wall thickness (2-4 mm) are surprising for a supposed Icacinaceae compared with modern species endocarps (Del Rio, 2018). Despite the fact that the wall anatomy, including interlocking digitate sclereids composing the endocarp and papillate locule lining, is a convincing argument for the proposed affinity, we decided to consider this species as dubious in order to consider the extreme differences in endocarp morphology. Icacinicarya mucronata, Icacinicarya bognorensis, Icacinicarya rotundata, and Icacinicarya sp.11 are considered as dubious in a recent revision of the London Clay fossils

150 (Stull et al., 2016), because of the lack of some characteristic features and the bad preservation of the specimens. We also followed this opinion here. Icacinicarya foveolata was considered as a non-member of the Icacinaceae family in the same study because of the presence of large hexagonal secretory cells lining the outside part of the seed and the thicker endocarp wall. In the absence of alternative identification and another argument, we consider that at least the characters given by Reid and Chandler (1933); i.e. endocarp unilocular and wall composed with partial digitate cells, are sufficient to not totally reject the potential affinity with Icacinaceae family, so we consider it as dubious. 

shape, the position of the vascular bundle and the stylar canal (Chandler, 1961b). However, the specimens are smooth, which is uncommon within the Icacinaceae family (Del Rio, 2018). This trait is occasionally found in Casimirella, Mappia and especially in Sarcostigma. Additionally, the wall is composed of non-digitate cells, $10-12 \mu \mathrm{m}$ in diameter. This kind of cells are never found in extant Icacinaceae (Del Rio 2018). Consequently, we rejected this species in our study. Icacinicarya budvarensis from the Santonian of Germany (Knobloch \& Mai, 1986) has a nodulose ornamentation, not common in the modern Icacinaceae family, and a shape also not found in extant species of Icacinaceae (Del Rio, 2018). Moreover, the description lacks the inner endocarp and the wall are partially not described. Therefore, we choose to consider this species as rejected. Icacinicarya papillaris (Knobloch \& Mai, 1986) resembles much more to an Icacinaceae especially belonging to Iodes, but the preservation seems to be insufficient to assign this species to a particular genus. We consider this species as dubious because of the rough ornamentation and the absence of the papillae on the inner endocarp surface. According to its original description, Iodes germanica, from the Maastrichtian of Germany, have all the diagnostic characters of Iodes (reticulate ornamentation, papillae on the inner surface, vascular bundle in one side on the endocarp wall; Knobloch \& Mai, 1986). Despite the lack of revision and a good illustration (Manchester, 2015), we decided to accept this last species as Icacinaceae member, based on the initial quite complete description. Icacinicarya sp. (Chester, 1955) is rejected for this paleogeographical reconstruction because of the doubtful age of the Nigeria outcrops. Chester writes "Maastrichtian?" for this specimen. Considering the importance of species from Cretaceous in paleogeographical 
reconstructions, we decided to not take the risk to include this specimen, not formerly described as a species by the author.

Icacinicarytes corruga (Pigg et al., 2008) lacks anatomical details and is based on a single unusually large specimen (38 $\mathrm{mm}$ x $28 \mathrm{~mm}$ ). In addition, the morphology of this specimen seems to be difficult to interpret, in particular the ornamentation different from extant Icacinaceae. We consider it as dubious.

Icacinicaryites israelii from the Early Maastrichtian of Israel was a controversial species. Some authors disputed the attribution of this specimen to Iodes (Stull et al., 2016; Del Rio et al., 2019a). In fact, this specimen lacks the anatomical detail needed to assign it. The potential inner cotyledon discussed in the original article (Soudry \& Gregor, 1997; figures $4,8,9$ ) seems to be an artefact. The specimen on which this species is based is bilateral, slightly compressed laterally, asymmetrical at the apex and reticulate on the surface. All these characters could support an Icacinaceae assignment. However, the reticulation pattern seems to be very orderly compared to Icacinaceae that have a more randomly arranged reticulation (Del Rio, 2018). The lack of anatomical detail on the wall and locules (Unilocular? Anatropous?) led us to consider this species as very questionable. Phytocrene microcarpa of Scott \& Barghoorn 1957 is rejected by some authors (Stull et al., 2012; Manchester et al., 2015). This species shows an anatomy that cannot match with the Icacinaceae family (Manchester et al., 2015). Also, the shape and the size of the endocarp do not match with this assignment. For this reason, we consider it as rejected. cf. Natsiatum wilkoxiana from the Eocene of the Tallahatta Formation (Blanchard et al., 2016) shows very few morphological clues and no anatomical characters. We cannot exclude that this specimen corresponds to Icacinaceae, because of the ridge structures described by the author. However, without enough diagnostic characters, we consider it as dubious. 
Some occurrences have been excluded from this study: an Iodes from the Miocene of

208 Yunnan (China) was mentioned by Stull et al. (2014) but not formerly published; one of us (DDF) could observe another Iodes species from the Miocene of Turkey, but could not study it in detail and the specimen is no longer accessible for study.

The leaves of modern Icacinaceae s.s. are in general simple, entire, mainly pinnatifid with brochidodromous secondary venation and percurrent tertiary venation (Sleumer, 1971; Villiers, 1973; Utteridge et al., 2007; Allen et al., 2015; and personal observation). There are some notable exceptions: leaves from Hosiea and Natsiatum are toothed with craspedodromous secondary veins; some Phytocrene and Pyrenacantha species have palmate primary veins (Phytocrene borneensis, P. bracteata, P. palmata, P. hirsuta, Pyrenacantha malvifolia). Tertiary veins are occasionally more reticulate as some species in Casimirella, Desmostachys, Miquelia, Pyrenacantha, and Stachyanthus in general. These examples show the great variation in leaf architecture in the family Icacinaceae but also the limited variation in the majority of species. Nevertheless, the classical type of leaves for Icacinaceae family is common in tropical flowering plants, at least for the entire leaves' trait (Bailey \& Sinnott, 1916; Wolfe, 1985). Thus, the leaves of this family lack diagnostic characters. While fossil leaves might appear identical in venation to modern leaves in the Icacinaceae, the fact that overlapping venation occurs in other families means that we cannot be fully confident in the identification of fossil leaves in this family. This probably explains the poor record of fossil leaves attributed to this family (only 13 occurrences). We choose to consider the leaves as dubious if no clear diagnostic characters are given. Menispermaceae (Wolfe, 1968), accommodates oval to lanceolate leaves with palmate primarily venation (in fact pinnatifid, see discussion in Allen et al., 2015), five primaries, 
correspond to Icacinaceae family but not exclusively. Indeed, we found a similar type of

233 leaves for at least the Metteniusaceae family (Fig. 1) in some genera previously considered as

234 Icacinaceae (Emmotum, Dendrobangia, Platea, Apodytes, Pittosporopsis, personal

235 observation). We decided to consider all Goweria species as dubious. Goweria linearis, in

236 particular, seems to be very ambiguous (Wolfe, 1968). Actually, the specimen has a strongly

237 asymmetrical apex, which is uncommon in Icacinaceae species. In our opinion, Goweria

238 bluerimensis is the most convincing assignment (Allen et al., 2015). These specimens possess

239 expanded petioles with a narrow, resistant vascular strand that could be a diagnostic character. Huziokaea eoutilus partially resembles Icacinaceae, but is closer to Gomphandra

(Tanai, 1990), which is currently in Stemonuraceae (Kårehed, 2001). The assignment of this extinct genus to Icacinaceae s.s is here considered as wrong.

Merrilliodendron ezoanum identification seems to be based on traits (wide-elliptic shape, intercostal tertiary veins, diverging perpendicular from the midvein), now shared by several families including Icacinaceae and Stemonuraceae (Tanai, 1990); we consider it as dubious.

The fossil record for Phytocrene leaves is composed of three species. However, Phytocrene acutissima from Eocene of Alaska corresponds to a partial fossil leaf (Wolfe, 1977; pl. 12, 1-6). Phytocrene sordida from Eocene of USA seems to be more convincing (MacGinitie, 1941), but the main traits correspond to the common characters discussed above for Goweria. The author of this species notes the similarity between the fossil species and modern Phytocrene blancoi and Hyperbaena hondurensis (Menispermaceae), showing the ambiguity of the determination at the family level. Finally, Phytocrene ozakii from the Eocene of Japan is based on a partial fossil (Tanai, 1990; pl. 6) and no diagnostic characters were clearly used. 
Both descriptions of Pyrenacantha sp. from Alaska and Japan (Wolfe, 1977; Tanai, 1990) are based on fragmentary material. They have mainly in common a pinnate venation and a weak pair of basal secondary venes that form marginal loops whose apical sides are oriented basally. This shape seems to appear many times in Asterids (e.g., Stemonuraceae, Lasianthera) and thus we consider these occurrences as dubious.

The genus Icaciniphyllum (not shown in Table 1.) was described for simple leaves, with a non-entire margin (undulate, crenulate, and irregularly dentate) and with craspedodromous venation (Kvaček \& Bůžek, 1995). These characteristics are rare in Icacinaceae. In fact, only Hosiea and Natsiatum could roughly correspond to this description, but the non-entire margin is very different. Other genera (e.g., Iodes, Pyrenacantha...) have entire margins and brochidodromous venation. Indeed, the type species Icaciniphyllum artocarpites (Ettingshausen) Kvaček \& Bůžek is now considered as a member of Sloanea L., (Elaeocarpaceae), which invalidates the previous assignment (Kvaček et al., 2001; Allen et al., 2015). Thus, the affinity is probably wrong for all the species attributed to the genus. To sum up, all fossil leaves are considered as dubious or as rejected for our paleogeographical reconstruction. We are convinced that some occurrences (e.g., Goweria bluerimensis) are adequately documented; however, we show that the main traits of leaves correspond mostly to the Icacinaceae s.l. are now shared by some more or less closely related families.

The fossil record of potential icacinaceous pollen is poor in term of species diversity but rich in occurrences, especially in Europe. To our knowledge, only one pollen type was considered as "Iodes type" in the USA (Leopold \& MacGinitie, 1972). This specimen was not represented nor described so we rejected this occurrence. The two other occurrences outside Europe are from the Miocene of Cameroon (Salard-Cheboldaeff, 1975). Echiperiporites minor is described as a periporate (5 pores) and echinulate pollen, which is apparently close to 
Phytocrene pollen. However, a re-examination of the original material (KWI-1 lame B,

282 W35/W36) led us to recognize about ten pores (J. Dejax com. Pers.), which allow the rejection of this species, because no modern Icacinaceae pollen shows more than eight pores (Lobreau-Callen, 1972). Echiperiporites icacinoides is described as three (4-5?) porate and echinulate pollen which could correspond to Stachyanthus, Deptaulus (Leptaulus?, Aquifoliaceae) and (mostly) Iodes. The original material is decayed. We are waiting for its potential restoration to eliminate the doubt and we decided here to reject this occurrence. Four species of the fossil pollen genus, Compositoipollenites, have been considered related to the Icacinaceae family. Manchester (2015) considers that "a comprehensive comparative investigation remains to be done with attention to other families that also share echinate pollen", in order to confidently conclude about the affinity of these pollen specimens. We decided to follow the same caution and we used the dubious status for all Compositoipollenites pollen.

The wood attributed to Icacinaceae possesses a wide occurrence and stratigraphic range (100.5-5.3 Ma). Unfortunately, they do not correspond to Icacinaceae s.s. and we rejected them all. Indeed, Icacinaceae s.s. have simple perforation plates (Lens et al., 2008), whereas Icacinoxylon has scalariform perforation plates. The explanation of this paradoxical nomenclature consists in the initial affinity of this fossil genus was made with Citronella, which is now in Cardiopteridaceae (Fig.1, Appendix), (Stull et al., 2015). The other wood taxon, Apodytoxylon hamamelidoides has Apodytes affinity, which is now in Metteniusaceae

301 family (Fig. 1, Appendix). 
We accepted 92 occurrences (mainly from endocarps), considered 45 occurrences as dubious (mainly leaves and pollen species) and rejected 46 occurrences (mainly from the wood species). According to our selection criteria, it has to be considered that all dubious species could be false identifications. We represent them in the following part in order to provide information about the potential range of the family, which could be a subject of discussion, only accepted species will be used in the biogeographic discussions.

The occurrences of Icacinaceae all belong to a warm temperate or boreotropical and tropical climate, except for the Paleocene Egyptian occurrence, which apparently belongs to an arid climate (Icacinicarya youssefi). The Northern Hemisphere, in particular European and North American areas, has almost all confident fossil occurrences. We have only one occurrence for the Cretaceous period and the most of the occurrences are from the early and middle-late Eocene. The Oligocene record is very poor. In term of (accepted) species richness (Table 2.), only one species belongs to the Cretaceous period, 14 are Paleocene, 59 are Eocene (38 from the early Eocene and 24 from the middle-late) and only 3 species are from the Oligocene epoch.

Records of Iodes extend from the Upper Cretaceous until the Oligocene. Phytocrene appears in the fossil record during the Paleocene or during the Eocene. Endocarp fossils of Pyrenacantha and Natsiatum were found during the Eocene, but only Pyrenacantha is known from the Oligocene. We did not identify other extant genera represented in the fossil record. No extinct genus is present during the Upper Cretaceous: almost all extinct records are found in the Paleogene, mainly during the Eocene epoch. Removing the unnatural genera (based on characters that allow us to assign specimens to Icacinaceae family, but not to a genus, e.g., Icacinicarya, Icacinicarytes), we can consider only one extinct genus during the Paleocene, six genera from the Eocene and one genus from the Oligocene. 


\subsection{Age of the family} The age of Icacinaceae was estimated at 96.7 Ma with the help of molecular phylogeny (Magallón et al., 2009). In another recent study, the estimated age was $104 \mathrm{Ma}$ (Wikström et al., 2015). This analysis used 17 fossil calibration points, but these are from various asterids, no Icacinaceae fossil records were included. In another molecular study, the estimated age is between 103 and $110 \mathrm{Ma}$, with the maximum likelihood method and between 65.5 and 100.3 Ma with a Bayesian analysis (Magallón et al., 2015). This last publication used numerous fossils as calibration points and in particular three fossils attributed to Icacinaceae family: Icacinoxylon alternipuncata, Icacinicarya papillaris, and Iodes germanica. The icacinaeous affinity of Icacinoxylon is rejected in this review, and Icacinicarya papillaris was considered as dubious. Only Iodes germanica seems to be an unambiguous Icacinaceae fossil. The authors used 65.5 Ma as the age of calibration base on this record. Two reviews of the fossil record of asteridae were made (Martínez-Millán, 2010; Manchester, 2015), highlighting a Maastrichtian minimum age for the Icacinaceae family. In our review of the fossil record, 13 species belong to the Cretaceous epoch but only Iodes germanica is accepted. The minimum appearance age selected for Iodes is $66 \mathrm{Ma}$ (Upper Maastrichtian, following the International chronostratigraphic chart v2017/02).

According to the previous studies, we consider the Upper Maastrichtian as the minimum age given by the fossil record for the Icacinaceae family. However, the calibration point for future molecular studies could be more precise including this minimum age at the internal node Iodes-Mappianthus (Stull et al., 2015) rather than at the Icacinaceae divergence. 


\subsection{Major changes in the family Icacinaceae}

In our review, only Iodes germanica species already occurs during the Upper Cretaceous of Europe, showing that the Icacinaceae family is present in Europe (Fig. 2A). This species is also found during the Upper Paleocene, at least this species crosses the Cretaceous-Palaeogene boundary and persists during the Paleocene in the same area. This could be a clue to the resilience of some families, and could explained by the previous results based on the family level showing that the land plants did not suffer from global extinction (but local turnover) during the Cretaceous-Palaeogene boundary (Cascales-Miñana \& Cleal, 2014). In addition, we show an increase of occurrences, genera, and species for the Icacinaceae family during the Paleocene and new occurrences outside of Europe, mainly in North America (Fig. 2B, Fig. 3), following the expansion of the boreotropical forest area (Mai, 1989; Wolfe, 1975). The genus Iodes seems to be limited to Europe during the Upper Cretaceous. With seven new Iodes species described for the Paleocene epoch, we show an increase of species richness. All species of Iodes from the Paleocene are very similar in term of shape and only differ for some precise traits (size of the endocarp, reticular pattern, shape of the ridges, Del Rio et al. 2019a).

We show a clear increase in Icacinaceae diversity during the early Eocene, in term of species, new genera with new shapes, (Fig. 3). Among the 14 species present from the Paleocene, only three species were found among the 38 early Eocene species. This shows a turnover and an increase of diversity in the Icacinaceae family. Two genera were more diverse, Palaeophytocrene and Iodes, which are probably climber species. This increase could be due to the new evergreen thermophilic flora, highly diversified and favourable to climbers, flora that occurs during the PETM (Upchurch Jr \& Wolfe, 1987; Collinson \& Hooker, 2003) and rapid turnover but not catastrophic changes for plants (Cavagnetto, 2000; Wing et al., 2005; Collinson et al., 2009; Pigg \& DeVore, 2009). In terrestrial diversity, studies show less 
perturbation but migrations of the fauna probably following the flora change (Godinot $\&$ de Broin, 2003; Gingerich, 2006).

The genus Palaeophytocrene only has one species from Bogota (South America) during the Paleocene and eight species during the Eocene from North America and Europe. This could indicate a diversification and an expansion of the area of Paleophytocrene during the PETM, following the expansion of the megathermal vegetation. Indeed, a geological connection between North and South America for the Paleophytocrene was proposed during the Paleocene (Stull et al., 2012). This connection became possible by the renewal of the magmatic arc of the Northern Andes during the Paleocene-Eocene (Bayona et al., 2011; Cardona et al., 2011). Therefore, this genus shows a strong evidence of potential exchanges between tropical South America and boreotropical flora during this period. Changes during the PETM in North America could be partially due to the flora spreading from South America, followed by an expansion of these floras to Europe during the late Ypresian. New endocarp shapes appeared at the end of early Eocene in Europe, as Faboidea, Perforatocarpum, Sphaeriodes, Stizocarya, all of these genera are now extinct. Among the eight Iodes species from the Paleogene, three were found from the early Eocene showing a partial but important change in Icacinaceae floristic composition (Del Rio \& De Franceschi, in press). In particular, among the 14 species that occur during the early Eocene, four have no horn-like protrusions at the apex (associated to the vascularisation of the fruit), whereas in the Paleocene, all Iodes species have it (Del Rio et al. 2019a). Thus, we found new shapes and new endocarp types during the early Eocene. These new shapes could be due to local diversifications or migrations of new floras from other areas. All species from the Paleocene are in Europe, whereas at least three species of Iodes (one with horn-like protrusions, two without) are in North America during the early Eocene. The connection between North America and Europe during the Paleocene and early Eocene was well-documented (Wolfe, 
1975; Manchester, 1994, 1999). This connexion remains possible via the North Atlantic land bridge (McKenna, 1975; Tiffney, 1985) and following the extension of the boreotropical forest during the global warming. The migrating direction of exchanges (Asia-North AmericaEurope or Asia-Europe-North America) was intensively discussed in mammal palaeontology (Godinot \& de Broin, 2003; Smith et al., 2006; Beard, 2008). Here, we have clues for an exchange from Europe during the early Eocene. In fact, all species with or without horn-like protrusions are older in Europe than in North America. However, an Iodes multireticulata specimen, dated from 55.5 Ma was found in the USA, the occurrence of this species in Europe was dated to about 51 Ma (Reid \& Chandler, 1933; Tiffney, 1999). Nevertheless, we suspected that the specimen from the Fisher/Sullivan site can be a new species instead of a specimen of I. multireticulata. In fact, the size of the specimens from Fisher and London Clay site seems distinctive. We show that the size of the endocarps could be used to differentiate modern species when it exists a clear gap between the sizes within species (Del Rio, 2018). This is here the case. With Iodes and Paleophytocrene, we have in consequence two examples of interchanges between North America and Europe, showing that the dispersion of floras was bilateral.

Due to particularly warm climate, the widest fossil extension of the Icacinaceae (in term of species richness and probable area) was reached during the early Eocene. However, this is from the middle-late Eocene that were found the fossil records attributed to modern genera as Natsiatum (Stull et al., 2011), Phytocrene, at first in Europe and then in the USA (Stull et al., 2011; Collinson et al., 2012) and Pyrenacantha (Manchester, 1994). Therefore, it is probably during the Eocene that the main modern genera appeared and diversified (Fig. 2D, Table 2). In Iodes, we show less species richness during the middle-late Eocene. These "species richness regression" could be attributed to the cooling climate (Collinson et al., 1981; Keller, 1983; Zachos et al., 2008), what Tiffney (1985) called a “climatic 
deterioration". This climate induced a change in floral structure, less favourable to the climber species (Collinson \& Hooker, 2003).

Only three occurrences of Icacinaceae were found during the Oligocene (Fig. 2E, Fig. 3B). This result shows an important decrease of diversity in the fossil record and is consistent with a regression of the boreotropical forest. At the Oligocene-Eocene boundary, the climate was probably the coolest of the Paleogene and remained cold throughout the Oligocene (Zachos et al., 2001, 2008). The boreotropical flora regressed and the deciduous vegetation, with less diversity, expanded (Tiffney, 1985). There are only two extant genera represented, Pyrenacantha and Iodes and one extinct genus, Palaeophytocrene. The species Pyrenacantha austroamericana is from the Oligocene of Peru (Stull et al., 2012). The oldest fossil remains of this genus is Pyrenacantha occidentalis of Lutetian age from Oregon, USA (Manchester, 1994). Thus, these two species show a connection between North and South America during the Eocene. On the other side, the Oligocene Iodes species is from Europe. This presence of this species allows for the consideration of Iodes as being present in Europe throughout the Palaeogene. This genus was probably part of a remnant of the boreotropical forest, also which is almost completely replaced in Europe by cold-tolerant species during the Neogene. (Wolfe, 1975, 1985, Tiffney, 1985). In this way, the Iodes fossil from Miocene of Turkey (DDF obs.) could also correspond to a late remain of this thermophilic European flora. Finally, Palaeophytocrene sp. from Oregon, USA also shows a symmetrical pattern in North American than Iodes in Europe (Meyer \& Manchester, 1997).

\subsection{Comparison with the history of other angiosperm families}

Our results are in accordance with the boreotropical regression hypothesis (Lavin \& Luckow, 1993). In particular, Wen (1999) establishes a disjunction of 65 genera between North 
American and Asian floras, which occurred during the Miocene. This pattern could be explained by an expansion of a boreotropical flora during the Paleocene and Eocene followed by a high regression during the Neogene.

Some families, including Icacinaceae and Menispermaceae, were considered as closely associated with the boreotropical flora (Wolfe, 1975). These two families have in common a majority of species with a climber habit and a similar present-day distribution. Thus, we can hypothesize that both families could have a similar history linked with the boreotropical expansion and regressions. A fossil history of the Menispermaceae was documented (Jacques, 2009). The Menispermaceae appeared during the Paleocene in the North America (Liu \& Jacques, 2010). However, this is probably a late refuge of the boreotropical flora. New studies show Menispermaceae in South America during the study on the genus Parthenocissus (climber) shows a disjunction between Asia and North America in the Early Miocene, which is congruent with the boreotropical regression (Nie et al., 2010, 2012). 
Some other evidence of expansion during the Paleogene and regression/extinction of

475 tropical floras in some areas (mainly North America and Europe) during the Neogene are found for Paliurus (Rhamnaceae), Sabiaceae family, Canarium (Burseraceae), Deviacer (?

(Anacardiaceae), (McClain \& Manchester, 2001; Manchester et al., 2007; Burge \&

Manchester, 2008; Wang et al., 2013; Zhang et al., 2013; Chen \& Manchester, 2015; Jia et al.,

2015; Han et al., 2018). Therefore, the results in the dynamic of flora on the Menispermaceae and other families are very congruent with what we found in the Icacinaceae family.

\section{Conclusion}

Among the 183 occurrences previously described as Icacinaceae, only 92 were accepted as belonging to this family in this study and are mainly from endocarp remains. The minimum age of the Icacinaceae family is probably the Upper Maastrichtian given by the fossil record for the Icacinaceae family. With the accepted samplings, we show an increase of the species richness during the Paleocene, probably due to the increase of temperature during the Thanetian. A great increase of diversity in term of genera, species, and morphology is shown through the Paleocene-Eocene boundary and during the Ypresian. Exchanges were shown between North America and Europe during the PETM in both ways. This is during the middle and late Eocene that most of the modern genera appear in the fossil record as Natsiatum, Phytocrene, and Pyrenacantha. Finally, the cooling period during the Oligocene, less favourable to climbers, could explain the decrease in the diversity of the Icacinaceae in the fossil record. We show the same pattern of diversification and regression in other megathermal families (Menispermaceae, Vitaceae...) showing a global dynamic of the North Hemisphere forest (boreotropical sensu. Wolfe, 1975) during the Paleogene. 


\section{Acknowledgments}

This work was supported by a grant from Agence Nationale de la Recherche under the LabEx ANR-10-LABX-0003-BCDiv, in the program "Investissements d'avenir" n_ ANR-11-IDEX0004-02 and by the CR2P (UMR 7207).

\section{Author Contributions}

DDF designed the project, CDR did the references work, CDR \& DDF wrote the manuscript and the discussion part.

\section{References}

Allen, S.E., Stull, G.W., Manchester, S.R., 2015. Icacinaceae from the Eocene of western North America. Am. J. Bot. 102(5), 725-744.

Akkiraz, M.S., Kayseri, M.S., Akgün, F., 2008. Palaeoecology of coal-bearing Eocene sediments in Central Anatolia (Turkey) based on quantitative palynological data. Turk. J. Earth Sci. 17(2), 317-360.

APG, 2016. An update of the Angiosperm Phylogeny Group classification for the orders and

Bailey, I.W., Sinnott, E.W., 1916. The climatic distribution of certain types of angiosperm families of flowering plants: APG IV. Bot. J. Linn. Soc. 141(4), 399-436. leaves. Am. J. Bot. 3(1), 24-39.

Bayona, G., Montes, C., Cardona, A., Jaramillo, C., Ojeda, G., Valencia, V., Ayala-Calvo, C., 2011. Intraplate subsidence and basin filling adjacent to an oceanic arc-continent collision: a case from the southern Caribbean-South America plate margin: Intraplate 
subsidence and basin filling adjacent to an oceanic arc-continent collision. Basin Res. 23(4), 403-422.

Beard, K.C., 2008. The oldest North American primate and mammalian biogeography during the Paleocene-Eocene Thermal Maximum. Proc. Natl. Acad. Sci. 105(10), 3815-3818.

Blanchard, J., Wang, H., Dilcher, D. L., 2016. Fruits, seeds and flowers from the Bovay and Bolden clay pits (early Eocene Tallahatta Formation, Claiborne Group), northern Mississippi, USA. Palaeontologia Electronica, 19(3), 1-59.

Boucot, A.J., Xu, C., Scotese, C.R., Morley, R.J., 2013. Phanerozoic paleoclimate: an atlas of lithologic indicators of climate. SEPM (Society for Sedimentary Geology) 11, 1-30.

Bowerbank, J.-S., 1840. A history of the fossil fruits and seeds of the London Clay. The Zoological society, London. 144 pp.

Brown, R.W., 1962. Paleocene flora of the Rocky Mountains and Great Plains. US Government Printing Office, Washington. 375, 179 pp.

Burge, D.O., Manchester, S.R., 2008. Fruit morphology, fossil history, and biogeography of Paliurus (Rhamnaceae). Int. J. Plant Sci. 169(8), 1066-1085.

Burnham, R.J., 1989. Relationships between standing vegetation and leaf litter in a paratropical forest: implications for paleobotany. Rev. Palaeobot. Palynol., 58(1), 5-32.

Burnham, R.J., Wing, S.L., Parker, G.G., 1992. The reflection of deciduous forest communities in leaf litter: implications for autochthonous litter assemblages from the fossil record. Paleobiology18(1), 30-49.

Byng, J.W., Bernardini, B., Joseph, J.A., Chase, M.W., Utteridge, T., 2014. Phylogenetic relationships of Icacinaceae focusing on the vining genera. Bot. J. Linn. Soc. 176(3), 277-294.

Cardona, A., Valencia, V.A., Bayona, G., Duque, J., Ducea, M., Gehrels, G., Jaramillo, C., Montes, C., Ojeda, G., Ruiz, J., 2011. Early-subduction-related orogeny in the northern 
Andes: Turonian to Eocene magmatic and provenance record in the Santa Marta Massif and Rancheria Basin, northern Colombia: Palaeogene subduction in the northern Andes. Terra Nova 23(1), 26-34.

Cascales-Miñana, B., Cleal, C.J., 2014. The plant fossil record reflects just two great extinction events. Terra Nova 26(3), 195-200.

Cavagnetto, C.G., 2000. La palynoflore d'un gisement d'ambre de l'Eocène basal du Bassin Parisien (Le Quesnoy, France). Palaeontographica Abteilung B 255(4-6), 147-171.

Chandler, M.E.J., 1925. The Upper Eocene flora of Hordle, Hants, Palaeontographical Society monographs, London. $52 \mathrm{pp}$.

Chandler, M.E.J., 1978. Supplement to the Lower Tertiary Floras of Southern England, Part 
Chen, Y., Manchester, S.R., 2015. Winged Fruits of Deviacer in the Oligocene from the Ningming Basin in Guangxi, South China. PloS one 10(12), e0144009

Chester, K., I., M., 1955. Some plant remains from the Upper Cretaceous and Tertiary of West Africa. Ann Mag Nat Hist 8(91), 498-504.

Cleal, C.J., Thomas, B.A., Batten, D.J., Collinson, M., E., 2001. Mesozoic and Tertiary paleobotany of Great Britain. Peterborough: Geological Conserv. Rev. Ser. 22, 335 pp.

Collinson, M.E., 1983. Fossil Plants of the London Clay. The Paleaeontological association, London. $121 \mathrm{pp}$.

Collinson, M.E., Hooker, J.J., 2003. Paleogene vegetation of Eurasia: framework for mammalian faunas. Deinsea 10(1), 41-84.

Collinson, M.E., Fowler, K., Boulter, M., 1981. Floristic changes indicate a cooling climate in the Eocene of southern England. Nature 291(5813), 315-317.

Collinson, M.E., Steart, D.C., Harrington, G.J., Hooker, J.J., Scott, A.C., Allen, L.O., Glasspool, I.J., Gibbons, S.J., 2009. Palynological evidence of vegetation dynamics in response to palaeoenvironmental change across the onset of the Paleocene-Eocene Thermal Maximum at Cobham, Southern England. Grana 48(1), 38-66.

Collinson, M.E., Manchester, S.R., Wilde, V., 2012. Fossil fruit and seeds of the Middle Eocene Messel biota, Germany, Abh. Senckenb. Ges. Naturforsch, Stuttgart. 251 pp.

Crane, P.R., Manchester, S.R., Dilcher, D.L., 1990. A preliminary survey of fossil leaves and well-preserved reproductive structures from the Sentinel Butte Formation (Paleocene) near Almont, North Dakota. Geology 20, 1-63.

Del Rio, C., 2018. Les Icacinaceae du Paléogène du Bassin de Paris. PhD diss. Muséum national d'Histoire naturelle, Paris. 
Del Rio, C., De Franceschi, D., Icacinaceae fossil fruits from three sites of the Paris Basin (early Eocene, France): local diversity and global biogeographic implications. Geodiversitas, In press (accepted 2019-06-25).

Del Rio, C., Haevermans, T., De Franceschi, D., 2017. First record of an Icacinaceae Miers fossil flower from Le Quesnoy (Ypresian, France) amber. Scientific reports, 7(1), 11099.

Del Rio, C., Thomas, R., De Franceschi, D., 2019a. Fruits of Icacinaceae Miers from the Palaeocene of the Paris Basin (Oise, France). Earth and Environmental Science Transactions of the Royal Society of Edinburgh, 108(4), 459-469.

Del Rio, C., Stull, G.W., De Franceschi, D., 2019b. New species of Iodes fruits (Icacinaceae) from the early Eocene Le Quesnoy locality, Oise, France. Review of Palaeobotany and Palynology. 262, 60-71.

Duperon, J., 1976. A propos de quelques bois fossiles du Sud-Ouest de la France. Bull. Société Bot. Fr. 123(9), 533-540.

Fairon-Demaret, M., Smith, T., 2002. Fruits and seeds from the Tienen Formation at Dormaal, Palaeocene-Eocene transition in eastern Belgium. Rev. Palaeobot. Palynol. $122(1-2), 47-62$.

Gingerich, P.D., 2006. Environment and evolution through the Paleocene-Eocene thermal maximum. Trends Ecol. Evol. 21(5), 246-253.

Godinot, M., de Broin, F. de L., 2003. Arguments for a mammalian and reptilian dispersal from Asia to Europe during the Paleocene-Eocene boundary interval. Deinsea 10(1), $255-276$.

Gottwald, H.P., 2000. Gymnosperme und dicotyle Hölzer (67) aus dem" Aachener Sanden" der Oberen Kreide von NO-Belgien und NW-Deutschland: mit anatomischer 
Bestimmung der Arten, Kommentaren, Tafeln und 96 Mikrofotos. Verlag Documenta Naturae 131, 1-44.

Grambast Fessard, N., 1969. Contribution à l'étude des flores tertiaires des régions provençales et alpines. V. Deux bois de dicotylédones à caractères primitifs du Miocène supérieur de Castellane. Nat. Monspel. 20, 105-118.

Greguss, P., 1969. Tertiary angiosperm woods in Hungary. Bp. Akad. Kiado. 151 pp.

Gruas-Cavagnetto, C., Tambareau, Y., Villatte, J., 1992. Découverte de pollens, Dinoflagellés et Forminifères dans le Danien des Petites Pyrénées: Implications sur la position de La Limite Crétacé/Tertiaire. Geobios 25, 19-28.

Han, M., Manchester, S.R., Wu, Y., Jin, J., Quan, C., 2018. Fossil fruits of Canarium (Burseraceae) from Eastern Asia and their implications for phytogeographical history. J. Syst. Palaeontol. 16(10), 841-852.

Heer, O., 1870. Die Miocene flora und fauna Spitzbergens. PA Norstedt \& söner, Stockholm. 98 pp.

Herendeen, P.S., 1991. Charcoalified angiosperm wood from the Cretaceous of eastern North America and Europe. Rev. Palaeobot. Palynol. 70(3), 225-239.

Herrera, F., Manchester, S.R., Hoot, S.B., Wefferling, K.M., Carvalho, M.R., Jaramillo, C., 2011. Phytogeographic implications of fossil endocarps of Menispermaceae from the Paleocene of Colombia. Am. J. Bot. 98(12), 2004-2017.

Herrera, F., Manchester, S.R., Carvalho, M.R., Jaramillo, C., Wing, S.L., 2014. Paleocene wind-dispersed fruits and seeds from Colombia and their implications for early Neotropical rainforests. Acta Palaeobot. 54(2), 197-229.

Hofmann, C.-C., Gregor, H.-J., 2018. Scanning electron microscope and light microscope investigations of pollen from an atypical mid-Eocene coal facies in Stolzenbach mine 
(Preuls senElektra) near Borken (Kassel, Lower Hesse, Germany). Rev. Palaeobot. Palynol. 252, 41-63.

646

647

Hofmann, C.-C., Mohamed, O., Egger, H., 2011. A new terrestrial palynoflora from the Palaeocene/Eocene boundary in the northwestern Tethyan realm (St. Pankraz, Austria). Rev. Palaeobot. Palynol. 166(3-4), 295-310.

Hollick, C.A., 1936. The tertiary floras of Alaska. US Gov't. Print. Off. 182, 185 pp.

Jacques, F.M.B., 2009. Fossil history of the Menispermaceae (Ranunculales). Ann. Paléontol. 95(2), 53-69.

Jaramillo, C., Cárdenas, A., 2013. Global warming and neotropical rainforests: a historical perspective. Annual Review of Earth and Planetary Sciences, 41, 741-766.

Jia, L.-B., Manchester, S.R., Su, T., Xing, Y.-W., Chen, W.-Y., Huang, Y.-J., Zhou, Z.-K., 2015. First occurrence of Cedrelospermum (Ulmaceae) in Asia and its biogeographic implications. J. Plant Res. 128(5), 747-761.

Jud, N.A., Nelson, C.W., Herrera, F., 2016. Fruits and wood of Parinari from the early Miocene of Panama and the fossil record of Chrysobalanaceae. Am. J. Bot. 103(2), 277-289.

Jud, N.A., Iglesias, A., Wilf, P., Gandolfo, M.A., 2018. Fossil moonseeds from the Paleogene of West Gondwana (Patagonia, Argentina). Am. J. Bot. 105(5), 927-942

Kårehed, J., 2001. Multiple origin of the tropical forest tree family Icacinaceae. Am. J. Bot. 88(12), 2259-2274.

Kedves, M., 1970. Études palynologiques des couches du Tertiaire inférieur de la région Parisienne.V. Pollen triporés, subtriporés et intratriporés. Pollen \& Spores 12(1), 83-97.

Kedves, M., Endredi, L., 1968. Palynologie investigations in the strata of «Buda Marl» with plantremains. Acta Biol 14, 1-4. 
Kedves, M., Pradutz, A., 1970. Études palynologiques des couches du tertiaire inférieur de la région Parisienne. VI. Ultrastructure de quelques pollens d'Angiospermes de l'Éocène inférieur (Sparnacien). Pollen \& Spores 12(4), 553-575.

Kedves, M., Russell, D.E., 1982. Palynology of the Thanetian layers of Menat. The geology of the Menat Basin, France. Palaeontogr. Abt. B 182(4-6), 87-150.

Keller, G., 1983. Paleoclimatic analyses of middle Eocene through Oligocene planktic foraminiferal faunas. Palaeogeogr. Palaeoclimatol. Palaeoecol. 43(1-2), 73-94.

Knobloch, E., Mai, D.H., 1986. Monographie der Fruchte und Samen in der Kreide von Mitteleuropa. Vydal Ustredni ustav geologicky, Praha. 219 pp.

Knobloch, E., Konzalova, M., 1998. Comparison of the Eocene plant assemblages of Bohemia (Czech Republic) and Saxony (Germany). Rev. Palaeobot. Palynol. 101(1-4), 29-41.

Krutzsch, W., Vanhoorne, R., 1977. Die Pollenflora von Epinois und Loksbergen in Belgien. Palaeontogr. Abt. B 163, 1-110.

Kvaček, Z., Bůžek, Č., 1995. Endocarps and foliage of the flowering plant family Icacinaceae from the Tertiary of Europe. Tert. Res. 15(3), 121-138.

Lavin, M., \& Luckow, M, 1993. Origins and relationships of tropical North America in the context of the boreotropics hypothesis. Am. Jour. of Botany, 80(1), 1-14.

Lens, F., Kårehed, J., Baas, P., Jansen, S., Rabaey, D., Huysmans, S., Hamann, T., Smets, E., 2008. The wood anatomy of the polyphyletic Icacinaceae s.l., and their relationships within asterids. Taxon 57(2), 525-552.

Lenz, O.K., Wilde, V., Riegel, W., 2007. Recolonization of a Middle Eocene volcanic site: quantitative palynology of the initial phase of the maar lake of Messel (Germany). Rev. Palaeobot. Palynol. 145(3-4), 217-242. 
Leopold, E.B., MacGinitie, H.D., 1972. Development and affinities of Tertiary floras in the Rocky Mountains. In A. Graham, ed., Floristics and paleofloristics of Asia and eastern North America. Elsevier Pubi. Co., Amsterdam. 147-200.

Liu, Y.-S. (Christopher), Jacques, F.M.B., 2010. Sinomenium macrocarpum sp. nov.

(Menispermaceae) from the Miocene-Pliocene transition of Gray, northeast Tennessee, USA. Rev. Palaeobot. Palynol. 159(1-2), 112-122.

MacGinitie, H.D., 1941. Middle Eocene flora from the central Sierra Nevada. Publ. Carnegie Inst. Washington 534, 1-178.

MacGinitie, H.D., 1969. The Eocene Green River flora of northwestern Colorado and northeastern Utah. University of California Press. 83, 1-202.

Magallón, S., Castillo, A., 2009. Angiosperm diversification through time. Am. J. Bot. 96(1), $349-365$.

Magallón, S., Gómez-Acevedo, S., Sánchez-Reyes, L.L., Hernández-Hernández, T., 2015. A metacalibrated time-tree documents the early rise of flowering plant phylogenetic diversity. New Phytol. 207(2), 437-453.

Mai, D.H., 1987. Neue Fruchte und Samen aus palaozanen Ablagerungen Mitteleuropas. Feddes Repert. 98, 197-229.

Mai, D.H., 1989. Development and regional differentiation of the European vegetation during the Tertiary, in: Woody Plants evolution and Distribution since the Tertiary. Springer, Vienna. 79-91.

Manchester, S.R., 1994. Fruits and seeds of the Middle Eocene nut beds flora, Clarno Formation, Oregon, Palaeontolographica Americana. Paleontological Research Institution, New York. 205 pp.

Manchester, S.R. 1999. Biogeographical relationships of North American tertiary floras. Annals of the Missouri Botanical Garden 86(2), 472-522. 
Manchester, S.R., Wilde, V., Collinson, M.E., 2007. Fossil cashew nuts from the Eocene of Europe: biogeographic links between Africa and South America. Int. J. Plant Sci. 168(8), 1199-1206.

Manchester, S.R., Chen, I., Lott, T.A., 2012. Seeds of Ampelocissus, Cissus, and Leea (Vitales) from the Paleogene of Western Peru and their biogeographic significance. Int. J. Plant Sci. 173(8), 933-943.

Manchester, S.R., Kapgate, D.K., Wen, J., 2013. Oldest fruits of the grape family (Vitaceae) from the Late Cretaceous Deccan Cherts of India. Am. J. Bot. 100(9) 1849-1859.

Manchester, S.R., Grímsson, F., Zetter, R., 2015. Assessing the fossil record of Asterids in the context of our current phylogenetic framework 1. Ann. Mo. Bot. Gard. 100(4), 329363.

Martínez-Millán, M., 2010. Fossil record and age of the Asteridae. Bot. Rev. 76(1), 83-135.

McClain, A.M., Manchester, S.R., 2001. Dipteronia (Sapindaceae) from the tertiary of North America and implications for the phytogeographic history of the Aceroideae. Am. J. Bot. 88(7), 1316-1325.

McKenna, M.C., 1975. Fossil mammals and early Eocene North Atlantic land continuity. Ann. Mo. Bot. Gard. 62(2), 335-353.

Meyer, H. W., Manchester, S. R., 1997. Oligocene Bridge Creek flora of the John Day Formation, Oregon. University of California Press 354 pp.

Morley, R.J., Dick, C.W., 2003. Missing fossils, molecular clocks, and the origin of the Melastomataceae. Am. J. Bot. 90(11), 1638-1644.

Nie, Z.-L., Sun, H., Chen, Z.-D., Meng, Y., Manchester, S.R., Wen, J., 2010. Molecular phylogeny and biogeographic diversification of Parthenocissus (Vitaceae) disjunct between Asia and North America. Am. J. Bot. 97(8), 1342-1353. 
Nie, Z.-L., Sun, H., Manchester, S.R., Meng, Y., Luke, Q., Wen, J., 2012. Evolution of the intercontinental disjunctions in six continents in the Ampelopsis clade of the grape family (Vitaceae). BMC Evol. Biol. 12(17), 1-13.

Pérez-Consuegra, N., Cuervo-Gómez, A., Martínez, C., Montes, C., Herrera, F., Madriñán, S., Jaramillo, C., 2017. Paleogene Salvinia (Salviniaceae) from Colombia and their paleobiogeographic implications. Rev. Palaeobot. Palynol. 246, 85-108.

Pérez-Consuegra, N., Góngora, D.E., Herrera, F., Jaramillo, C., Montes, C., Cuervo-Gómez, A.M., Hendy, A., Machado, A., Cárdenas, D., Bayona, G., 2018. New records of Humiriaceae fossil fruits from the Oligocene and Early Miocene of the western Azuero Peninsula, Panamá. Bol. Soc. Geológica Mex. 70(1), 223-239.

Petrescu, J., Dragastan, O., 1972. Asupra unor lemne de Icacinoxylon Shilkina din oligocenul de la Telega-Prahova. Stud. Cerc Geol Geofiz Geog Ser Geol 17, 445-451.

Petrescu, I., Nutu, A., 1972. Asupra unui lemn de Icacinoxylon Sh. in micenul superior de la Pravaleni. Brad. Sargetia Ser Sc 9, 77-79.

Petrescu, I., Codrea, V., 2004. The signification of the Paleocene microflora from Jibou (Sălaj District) for the Paleogene palinological heritage of Romania. Acta Palaeontol. Romaniae 4, 351-360.

Petrescu, I., Ghiurca, V., Nica, V., 1989. Paleobotanical and palynological researches on the lower-Oligocene amber and amber-bearing formation at Colti-Buzau. Oligocene Transylv. Basin 183-198.

Pigg, K.B., Wher, W.C., 2002. Tertiary flowers, fruits, and seeds of Washington State and adjacent area-Part III. Washington Geology 30(3/4), 3-16.

Pigg, K.B., DeVore, M.L., 2009. Floristic composition and variation in late Paleocene to early Eocene floras in North America. Bull. Geosci. 85(1), 135-154. 
Pigg, K.B., Manchester, S.R., DeVore, M.L., 2008. Fruits of Icacinaceae (Tribe Iodeae) from the Late Paleocene of western North America. Am. J. Bot. 95(7), 824-832.

Potonié, R., 1960. Synopsis der Gattungen der Sporae dispersae: III. Beib. Geol. Jahrb. 39, 1-189.

Potter, J.F., 1977. Eocene, lower Bracklesham Beds, iron workings in Surrey. Proc. Geol. Assoc. 88(4), 229-241.

Rankin, B.D., Stockey, R.A., Beard, G., 2008. Fruits of Icacinaceae from the Eocene Appian Way Locality of Vancouver Island, British Columbia. Int. J. Plant Sci. 169(2), 305314.

Reid, E.M., Chandler, M.E.J., 1933. The London Clay Flora. The British Museum (Natural History), London. $561 \mathrm{pp.}$

Salard-Cheboldaeff, M., 1975. Quelques grains de pollen périporés tertiaires du Cameroun. Rev. Micropaleontol. 17(4), 182-190.

Scott, R.A., 1954. Fossil fruits and seeds from the Eocene Clarno Formation of Oregon. Palaeontogr. Abt. B 66-97.

Scott, R.A., Barghoorn, E.S., 1957. Phytocrene microcarpa-a new species of Icacinaceae based on Cretaceous fruits from Kreischerville, New York. The Paleobotanist. 25-28.

Sleumer, H., 1942. Icacinaceae. In Engler, A. (ed) Die Natürlichen Pflanzenfamilien, Leipzig: Engelmann 20b, 322-396.

Sleumer, H., 1971. Icacinaceae, in: Flora Malesiana. CGGJ van Steenis, Noordhoff (ed), Leiden. 7(1), 1-87.

Smith, T., Rose, K.D., Gingerich, P.D., 2006. Rapid Asia-Europe-North America geographic dispersal of earliest Eocene primate Teilhardina during the Paleocene-Eocene thermal maximum. Proc. Natl. Acad. Sci. 103(30), 11223-11227. 
Soudry, D., Gregor, H.-J., 1997. Jodes israelii sp. nov.: a huge phosphate-mineralized icacinacean fructification from the Late Cretaceous of the Negev, southern Israel. Cretac. Res. 18(2), 161-178.

Stull, G.W., Moore, B.R., Manchester, S.R., 2011. Fruits of Icacinaceae from the Eocene of southeastern North America and their biogeographic implications. Int. J. Plant Sci. 172(7), 935-947.

Stull, G.W., Herrera, F., Manchester, S.R., Jaramillo, C., Tiffney, B.H., 2012. Fruits of an "Old World" tribe (Phytocreneae; Icacinaceae) from the Paleogene of North and South America. Syst. Bot. 37(3), 784-794.

Stull, G.W., Duno de Stefano, R., Soltis, D.E., Soltis, P.S., 2015. Resolving basal lamiid phylogeny and the circumscription of Icacinaceae with a plastome-scale data set. Am. J. Bot. 102(11), 1794-1813.

Stull, G.W., Adams, N.F., Manchester, S.R., Sykes, D., Collinson, M.E., 2016. Revision of Icacinaceae from the Early Eocene London Clay flora based on X-ray micro-CT. Botany 94(9), 713-745.

Takahashi, K., Suzuki, M., 2003. Dicotyledonous fossil wood flora and early evolution of wood characters in the Cretaceous of Hokkaido, Japan. Iawa Journal 24(3), 269-309.

Takhtajan, A., 1966. Major phytochoria of the Late Cretaceous and the Early Tertiary on the territory of the USSR and adjacent countries. Bot. Zh. 51, 1217-1230.

Tanai, T., 1990. Euphorbiaceae and Icacinaceae from the Paleogene of Hokkaido, Japan. Bull. Natn. Sci. Mus. Tokyo Ser C. 16(3), 91-118.

Thayn, G.F., Tidwell, W.D., Stokes, W.L., 1985. Flora of the Lower Cretaceous Cedar Mountain Formation of Utah and Colorado. Part III: Icacinoxylon pittiense n. sp. Am. J. Bot. 72(2), 175. 
813 Thiele-Pfeiffer, H., 1988. Die Mikroflora aus dem mitteleozänen Ölschiefer von Messel bei

814 Darmstadt. Palaeontogr. Abt. B 211(1-3), 1-86.

815 Thomson, P.W., Pflug, H.D., 1953. Pollen und Sporen des mitteleuropäischen Tertiärs.

$816 \quad$ Palaeontogr. Abt. B 1-138.

817 Tichy, G., 1979. On the occurrence of fruits of Icacinaceae from the Eocene of St. Prankraz 818 near Salzburg and the Kressenburg in Upper Bavaria. Verh Geol B-A 3: 415-421.

819 Tiffney, B.H., 1999. Fossil fruit and seed flora from the early Eocene fisher/sullivan site, in: 820 Early Eocene Vertebrates and Plants from the Fisher/Sullivan Site (Nanjemoy

Tuzson, J., 1906. A balatoni fossilis fak monografiaja. [A monograph of the fossil plant remains from the Balaton region.]. Bal. Tud Tanulmanyozasanak Eredmenyei 1, 1-56.

Upchurch Jr, G., Wolfe, J., 1987. Mid-Cretaceous to Early Tertiary vegetation and climate: evidence from fossil leaves and woods, in: The Origins of Angiosperms and Their Biological Consequences, EM Friis, WG Chaloner, and PR Crane (ed), England. 75-

Utteridge, T., Nagamasu, H., Teo, S., White, L., Gasson, P., Brummitt, R., 2007. Icacinaceae. Flower. Plant Fam. World 173.

Villiers, J.-F., 1973. Icacinaceae, in: Flore Du Cameroun. A. Aubréville et J-F. Leroy (ed), Paris, France. 3-100.

Von Ettingshausen, C., 1869. Die fossile flora des Tertiär-Beckens von Bilin. K. Gerold's Sohn. 110 pp. 
Wang, Q., Manchester, S.R., Gregor, H.-J., Shen, S., Li, Z.-Y., 2013. Fruits of Koelreuteria (Sapindaceae) from the Cenozoic throughout the northern hemisphere: Their ecological, evolutionary, and biogeographic implications. Am. J. Bot. 100(2), 422-449.

Wen, J., 1999. Evolution of eastern Asian and eastern North American disjunct distributions in flowering plants. Annu. Rev. Ecol. Syst. 30(1), 421-455.

Wheeler, E.A., Lee, M., Matten, L.C., 1987. Dicotyledonous woods from the Upper Cretaceous of southern Illinois. Bot. J. Linn. Soc. 95(2), 77-100.

Wikström, N., Kainulainen, K., Razafimandimbison, S.G., Smedmark, J.E.E., Bremer, B., 2015. A revised time tree of the asterids: establishing a temporal framework for evolutionary studies of the coffee family (Rubiaceae). PLoS ONE 10(5), 1-26, e0157206.

Wing, S.L., Harrington, G.J., Smith, F.A., Bloch, J.I., Boyer, D.M., Freeman, K.H., 2005. Transient floral change and rapid global warming at the Paleocene-Eocene boundary. Science 310(5750), 993-995.

Wolfe, J.A., 1968. Paleogene biostratigraphy of nonmarine rocks in King County, Washington. U.S. Geol. Surv.Prof. Paper 571.

Wolfe, J.A., 1975. Some aspects of plant geography of the Northern Hemisphere during the late Cretaceous and Tertiary. Ann. Mo. Bot. Gard. 62(2), 264-279.

Wolfe, J.A., 1977. Paleogene floras from the Gulf of Alaska region. U.S.GS. Prof. Paper 997.

Wolfe, J.A., 1985. Distribution of major vegetational types during the Tertiary. The carbon cycle and atmospheric CO2. Nat. Var. Archean Present 32, 357-375.

Zachos, J.C., Pagani, M., Sloan, L., Thomas, E., Billups, K., 2001. Trends, rhythms, and aberrations in global climate 64 Ma to Present. Science 292(5517), 686-693.

Zachos, J.C., Dickens, G.R., Zeebe, R.E., 2008. An early Cenozoic perspective on greenhouse warming and carbon-cycle dynamics. Nature 451(7176), 279-283. 
862 Zhang, J.-B., Li, R.-Q., Xiang, X.-G., Manchester, S.R., Lin, L., Wang, W., Wen, J., Chen,

863 Z.-D., 2013. Integrated fossil and molecular data reveal the biogeographic

864 diversification of the Eastern Asian-Eastern North American disjunct Hickory Genus

865 (Carya Nutt.). PLoS ONE 8, e70449.

866 


\section{Figure caption}

868

869 Figure 1. Phylogeny of Asterids following APG IV. In red: Position of the genera of

870 Icacinaceae s.l. (Sleumer, 1942). The asterix indicates the emplacement of the Icacinaceae s.s.

871 as circumscribed by Stull et al. (2015).

872 Figure 2. Paleomaps showing the distribution of the Icacinaceae family in the fossil record.

873 (A) Upper Cretaceous, (B) Paleocene, (C) early Eocene, (D) middle-late Eocene and (E)

874 Oligocene. Red dots: accepted occurrence; grey squares: dubious occurrence. Paleomaps 875 modified from Boucot et al., 2013.

876 Figure 3. Diversity of Icacinaceae (A) Number of genera by ages, (B) Number of species by

877 ages, (C) Number of Iodes species by ages. C: Cretaceous, P: Paleocene, E: Eocene, O:

878 Oligocene. 
A

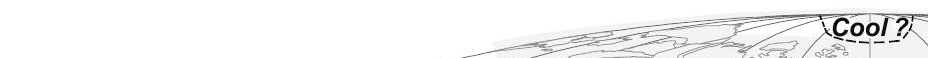

Warm Temperate

Warm Temperate

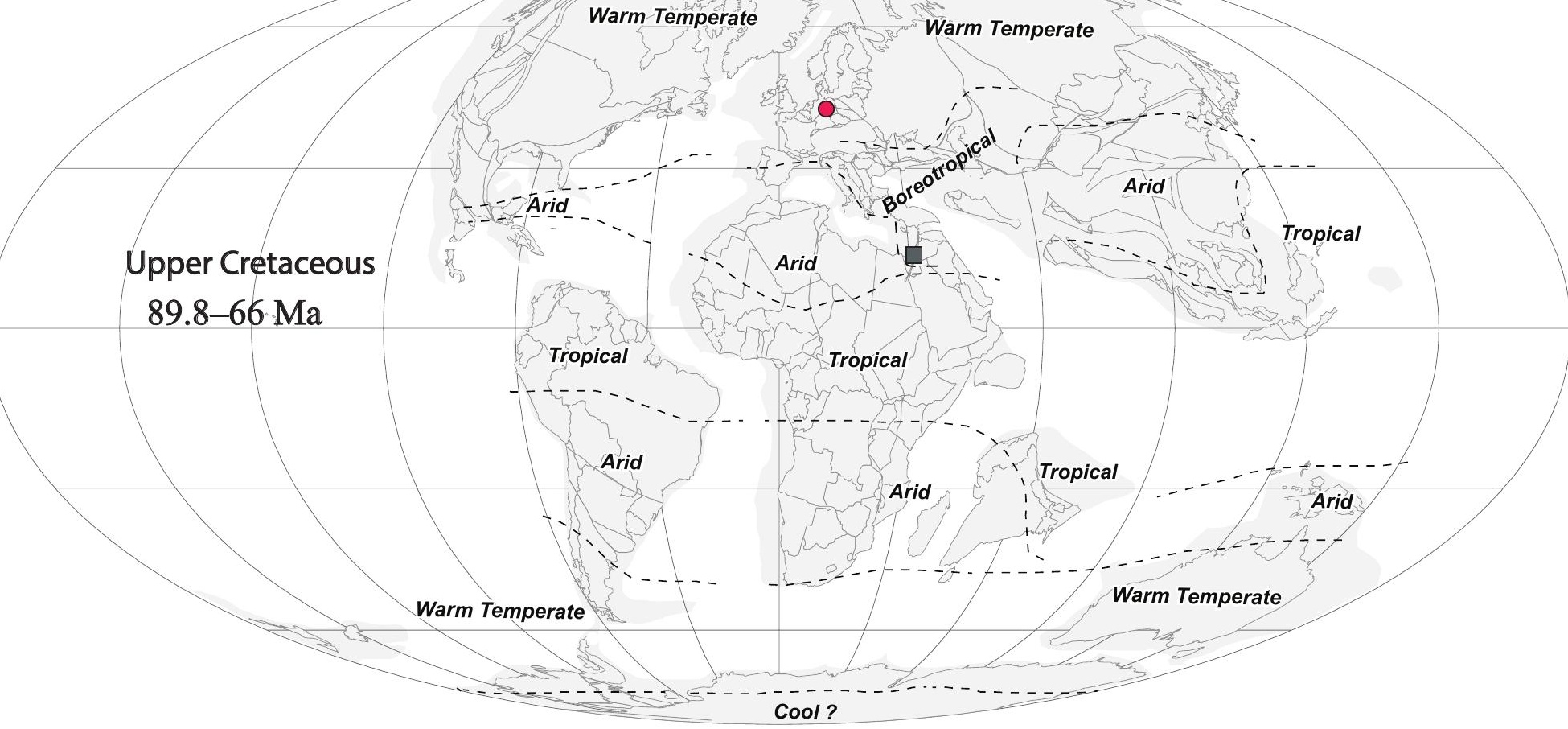

B

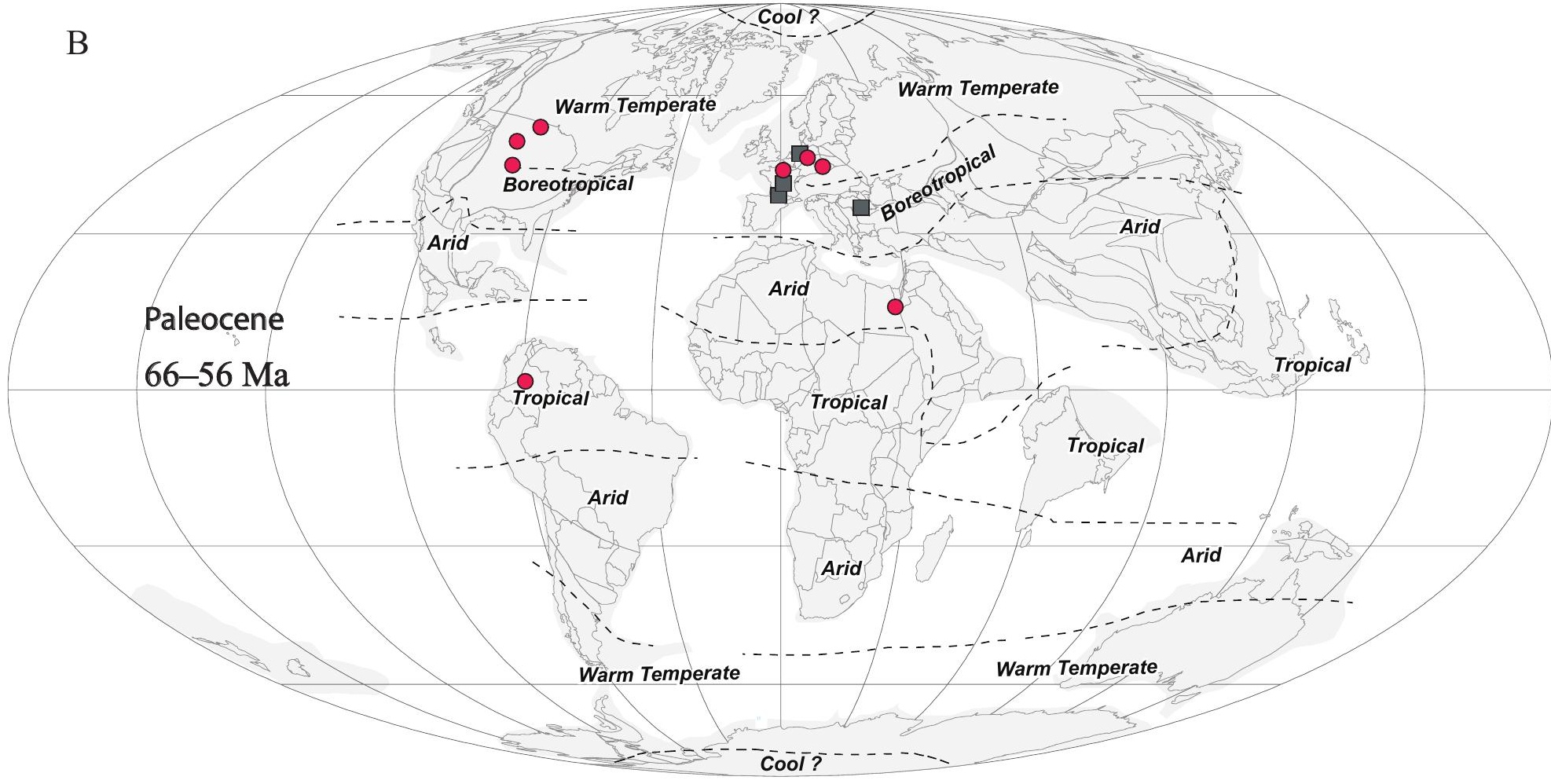

C
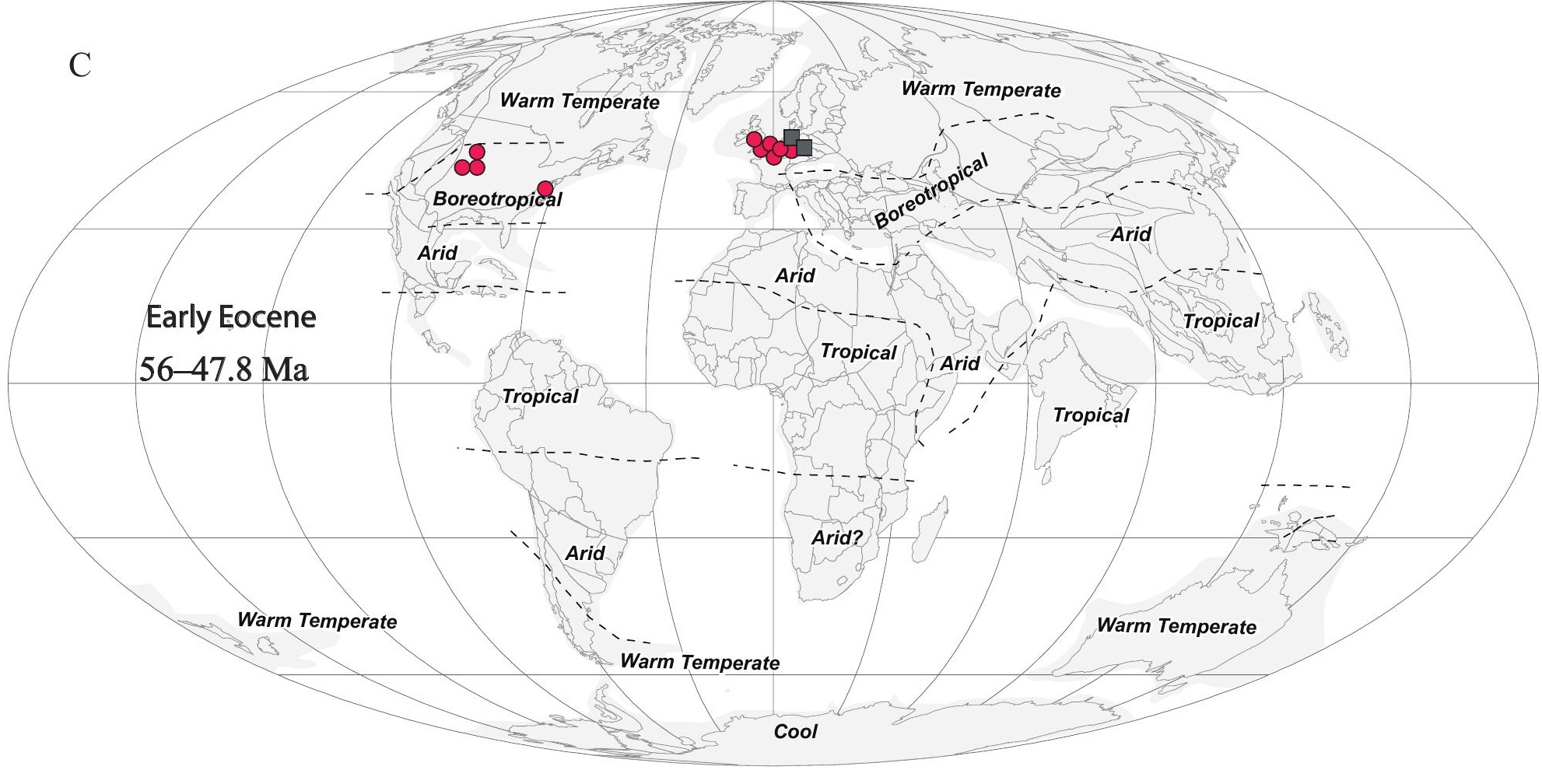

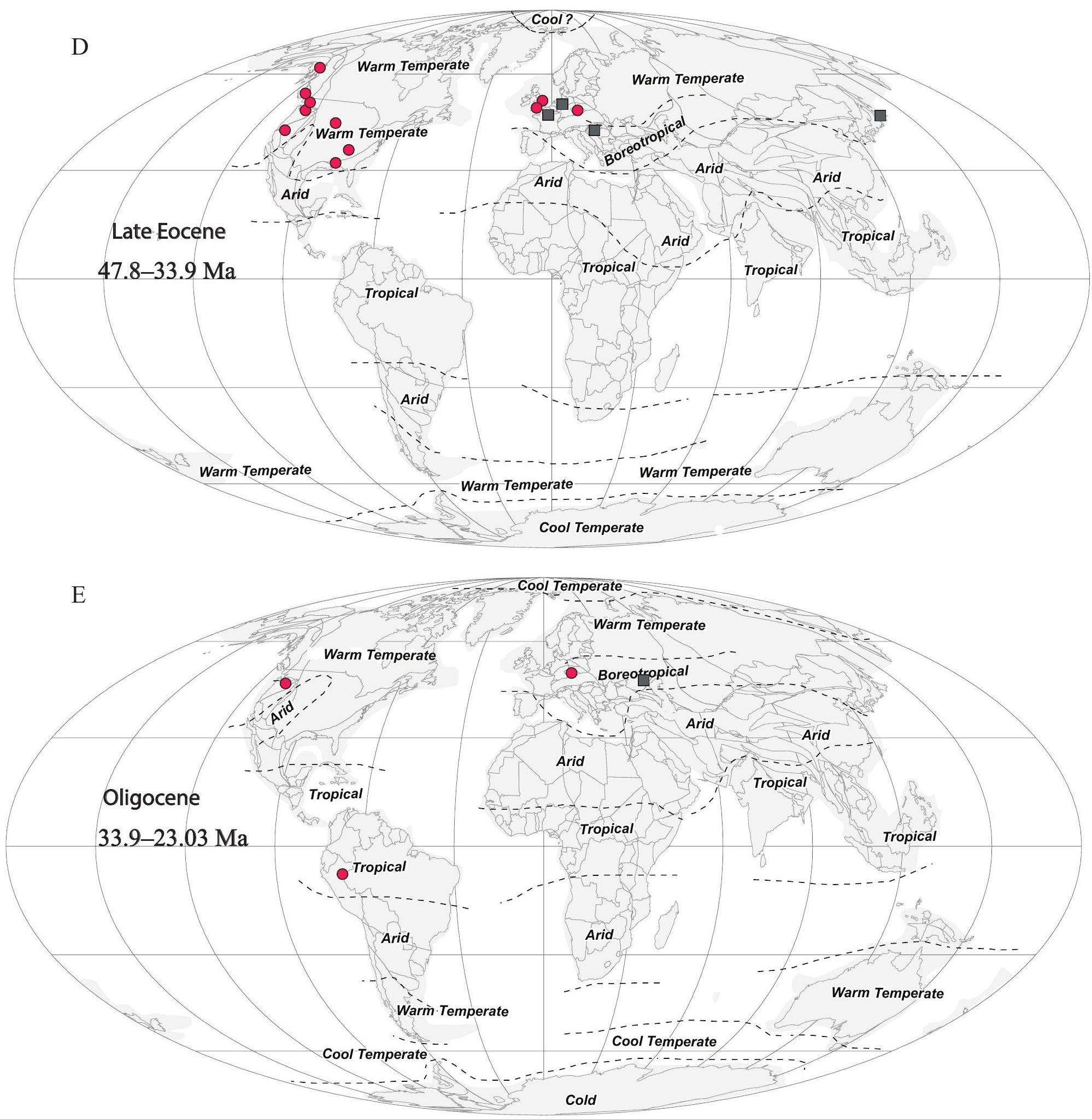
A

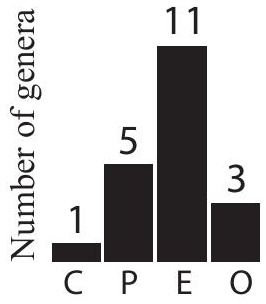

B

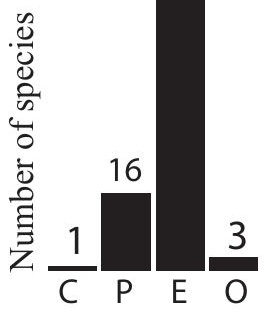

$\mathrm{C} \frac{\tilde{d}}{\tilde{d}}$

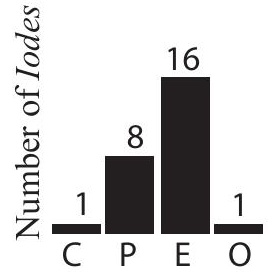




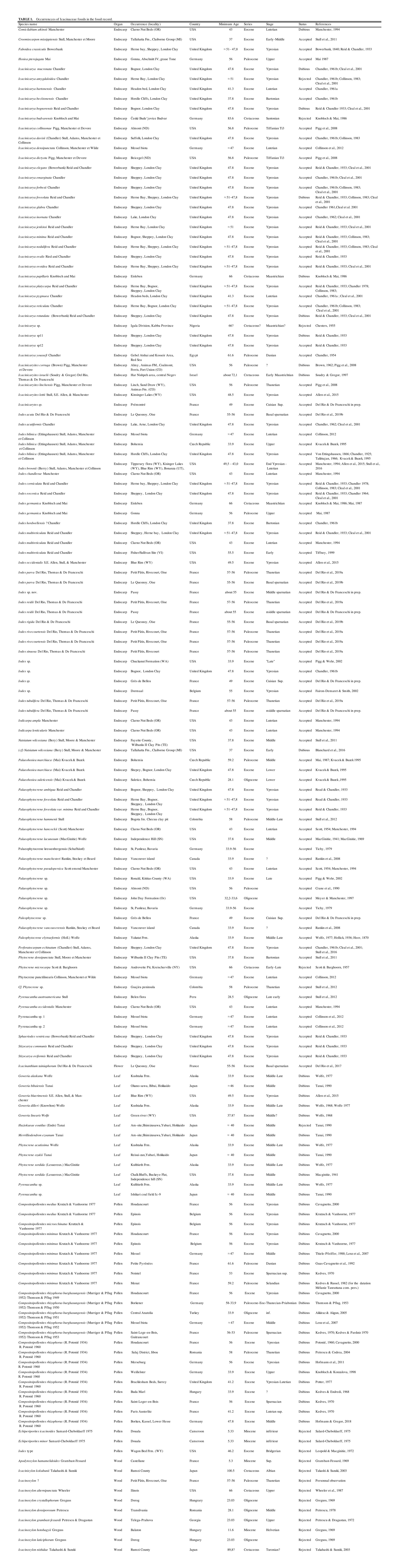




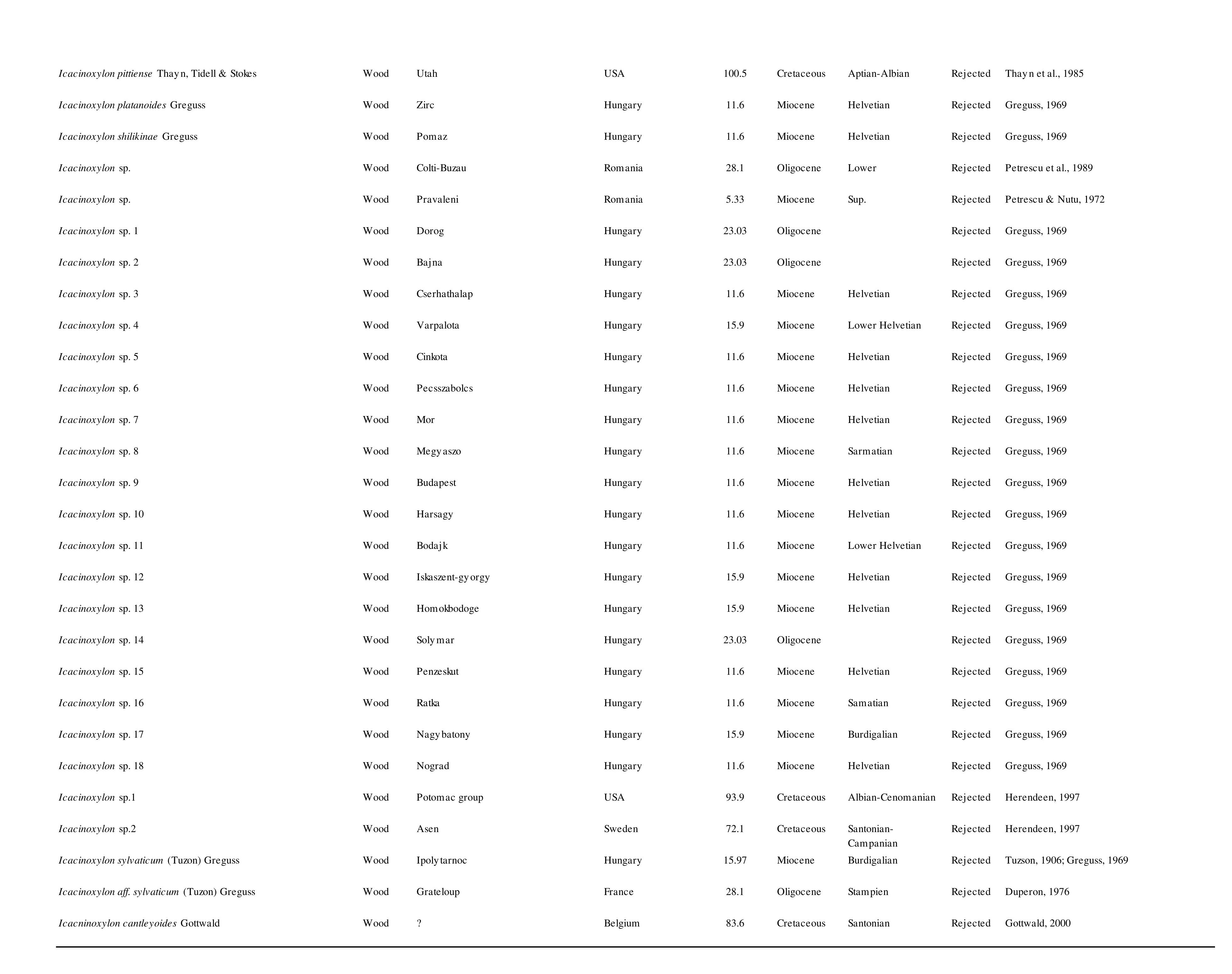


TABLE 2. Number of species of extinct and modern Icacinaceae accepted genera in different epochs. Palaeohosiea, Hosiea and Croomiocarpum species are considered as part of Iodes.

\begin{tabular}{|c|c|c|c|}
\hline Epoch & Number of species & Extinct genus & Modern genus \\
\hline Oligocene & 3 & Palaeophytocrene & $\begin{array}{l}\text { Iodes (Palaeohosiea) } \\
\text { Pyrenacantha }\end{array}$ \\
\hline Eocene & 59 & $\begin{array}{l}\text { Faboidea } \\
\text { Icacinanthium } \\
\text { Icacinicarya } \\
\text { Iodicarpa (Iodes?) } \\
\text { Palaeophytocrene } \\
\text { Perforatocarpum } \\
\text { Sphaeriodes } \\
\text { Stizocarya }\end{array}$ & $\begin{array}{l}\text { Iodes ( Iodes, } \\
\text { Croomiocarpum, } \\
\text { Palaeohosiea) } \\
\text { Natsiatum } \\
\text { Phytocrene } \\
\text { Pyrenacantha }\end{array}$ \\
\hline Paleocene & 16 & $\begin{array}{l}\text { Icacinicarya } \\
\text { Icacinicarytes } \\
\text { Palaeophytocrene }\end{array}$ & $\begin{array}{l}\text { Iodes (Iodes, Palaeohosiea, } \\
\text { Hosiea) } \\
\text { Phytocrene? }\end{array}$ \\
\hline Upper Cretaceous & 1 & $\varnothing$ & Iodes \\
\hline
\end{tabular}

